\title{
Arbitrability of Administrative Contracts Under Ethiopian Legal System: Critical Appraisal
}

\author{
Mulisa Mergo Bulto \\ School of Law, Wollega University, P. O. Box 395, Nekemte, Ethiopia
}

\begin{abstract}
Disputes or differences between or claims of the parties which may arise from certain legal relationship could be settled outside of ordinary courts through the mechanism called alternative or amicable dispute resolution mechanisms, alternative to the litigation. These extra-judicial mechanisms of resolving disputes or differences or claims of the parties, inter alia, are negotiation, mediation and arbitration. The first two are essentially negotiation mechanisms and the third one is decisional mechanism where parties' appointed judges or experts give decision on the point on which parties are at issue based on the principles of the law. The point of worth consideration is to wonder if all matters are capable of settlement by arbitration. Based on county's public policy consideration, some matters are arbitrable whereas other matters are in arbitrable. The objective of this paper is to analyze whether disputes emanating from administrative contracts are capable of settlement by arbitration or otherwise in Ethiopia under the relevant laws and to survey what the practice looks like in relation to the same. Thus, doctrinal legal research methodology is employed to attain the objective. The findings of the study reveal that there is no uniform practice as to arbitrability of administrative contracts in Ethiopia and there is also no administrative procedure legislation that addresses the problem at hand.
\end{abstract}

Keywords: arbitrability Administrative contracts Alternative Dispute Resolution

DOI: $10.7176 / \mathrm{JLPG} / 105-02$

Publication date: January $31^{\text {st }} 2021$

\section{Introduction}

Dispute refers to a conflict or controversy; a conflict of claims or rights; an assertion of a right, claim, or demand on one side, met by contrary claims or allegations on the other. ${ }^{1}$ Alternative dispute resolution mechanisms are mechanisms of resolving disputes in general and commercial disputes in particular extra-judicially. They are, as the name is self-explanatory, alternative to the court litigation in resolving disputes.

Negotiation is one of the alternative dispute resolution mechanisms where the parties themselves try it to settle their dispute without the involvement of the neutral third party. Mediation which is essentially a mechanism of negotiation also is alternative dispute resolution mechanism where the disputants try to settle their disputes with the help of the neutral third-party mediator(s). Arbitration, a form of alternative dispute resolution, is a technique for the resolution of disputes outside the courts where the parties to a dispute refer it to arbitration by one or more persons (the arbitrators, arbiters or arbitral tribunal), and agree to be bound by the arbitration decision (the award).

Arbitration which is not mechanism of negotiation but a decisional process also falls in the species of the alternative dispute resolution mechanisms. The latter in majority of cases is consensual i.e. arises from the contracts unless it arises from the mandatory provisions of the law like the case of compulsory or mandatory arbitration. That is to say, disputant parties may consensually agree to settle their dispute through arbitration unless otherwise provided by the mandatory provision(s) of the law.

\section{The Notion of Arbitrability: What is it?}

The notion of arbitrability is a concept that implies the existence of matter(s) that can be adjudicated by arbitration and that cannot be adjudicated by arbitration. In literature matter(s) amenable to arbitration are called arbitrable matter(s) and matter(s) not amenable to arbitration are called non-arbitrable matter(s). ${ }^{3}$ Thus, the notion of arbitrability is bi-dimensional such that it directly deals with the appraisal of which matter(s) are amenable to arbitration and which are not amenable to arbitration. The basic justification for this notion of arbitrability in effect is public policy consideration in order to limit the scope of arbitration as a mechanism of resolving disputes. ${ }^{4}$

As the public policy of countries may vary, each country may thus decide which matter(s) may be settled by arbitration and which matter(s) may not in accordance with its own public policy consideration. Therefore, countries may, under their domestic laws considering their public policy, envisage disputes that emanate from certain matter(s) arbitrable and disputes that emanate from certain matter(s) in arbitrable. The latter is where the law prohibits arbitration of certain matter(s). The public policy consideration of a country thus reflected in its law

\footnotetext{
${ }^{1}<\mathrm{a}$ href="http://legal-dictionary.thefreedictionary.com/dispute" $>$ dispute</a>, accessed on 16, February, 2019.

${ }^{2}$ https://en.wikipedia.org/wiki/Arbitration, accessed on 16, February, 2019

3 Wondwossen Wakene, Law of Administrative contracts material for Study ,2009, p.113

${ }^{4}$ Ibid.
} 
determines whether dispute arise from certain matter(s) is/are capable of settlement by arbitration or otherwise. The commercial realities of a country can also be another possible factor that may determine the arbitrability of matters. ${ }^{1}$

The inferable point from these explanations is that matter(s) capable of settlement by arbitration in some states may constitute in arbitrable matter(s) in other states. And this has an effect on the recognition and enforcement of foreign awards.

\subsection{What are administrative contracts under Ethiopian law?}

As defined under the Ethiopian civil code, contract is an agreement whereby two or more persons as between themselves create, vary or extinguish obligation of a proprietary nature. ${ }^{2}$ The point is that since administrative contracts are also contracts, they do share all of the elements of the above definition of contract. Needless to say, administrative contracts also are required to comply with the requirements of consent, capacity, object and form, if any, like other contracts. ${ }^{3}$

However, what qualifies administrative contracts is that its requirements go beyond the requirements envisaged hereinabove as it is observed from the provisions of civil code specifically dealing with the administrative contracts as we will see below. The Ethiopian Civil Code clearly provides the yardsticks that help us to ascertain whether certain contract is administrative contract or otherwise, requirements that qualifies a contract as administrative contracts and there by differentiate it from ordinary civil contracts.

Accordingly, a contract shall be deemed to be an administrative contract where: it is expressly qualified as such by law or by the parties; or it is connected with an activity of the public service and implies a permanent participation of the party contracting with the administrative authorities in the execution of such services; or it contains one or more provisions which could only have been inspired by urgent consideration of the general interest extraneous to relations between private individuals. ${ }^{4}$ According to the first yardstick, a contract as defined hereinabove under article 1675 of Civil Code will be an administrative contract if the law qualifies it as administrative contract.

The instance of contracts which the law qualifies as administrative contracts are in the case of concession of public services $^{5}$, public supply contracts ${ }^{6}$ and contracts of public services. ${ }^{7}$

The other requirement provided by the code to ascertain whether certain contract is administrative contract is that where the parties qualify it as administrative contract. But an issue of worth rising at this juncture will be to wonder if all contracts are administrative contracts merely because qualified by the parties as administrative contracts. Superficially, the requirement is saying that the contract qualified by parties as an administrative contract can be the same but a contract qualified as such by the parties on face value can't be considered as an administrative contract unless one of the parties is an administrative authority provided that the object of the contract such as activity of public service as we can understand from article 3207(b) of Civil Code.

Here my argument is that a contract could not be an administrative contract for the mere fact that it is qualified as such by the parties unless one of the parties is an administrative authority or agency (as we can see from article 3132(b)) which still should be identified in reference to the object of the administrative contract such as the public service under concession of public service which is one instance of administrative contract.

The point is that object of administrative contract is also one factor that helps us to distinguish administrative contracts from ordinary contracts and contract with administrative authority become administrative contract where it is concluded to, for instance, carry out public service activities.

The other criterion employed by the code to ascertain whether a contract is administrative contract or not is that the connection of the contract with an activity of the public service and implies permanent participation of the party contracting with administrative authorities in the execution of such service. The examination of this element of definition in the way of ascertaining what constitutes administrative contract reveals that for a contract to be administrative contract it should have connection with an activity of public service and a party who conclude the contract with administrative authority is to execute or accomplish activities of the public service.

Thus, it is tenable to argue that administrative contracts are contracts that a party may conclude with administrative authorities to execute the activity of public service. What one may wonder at this point is who administrative authorities or agencies are. Due to the absence of the administrative procedure proclamation or law in Ethiopia, there is no comprehensive definition of administrative authority. But in literature some parameters are employed to differentiate what government organs can be considered as administrative authority or agency or

\footnotetext{
${ }^{1}$ Zakarias Kaneaa, Arbitrability in Ethiopia: posing problem, Journal Ethiopian Law, vol.17, 1994, p. 117

${ }^{2}$ The Ethiopian Civil Code, article 1675

${ }^{3}$ Id, article 1678

${ }^{4} \mathrm{Id}$, article 3132

${ }^{5}$ Id, article $3207-3243$

${ }^{6}$ Id, articles 3297-3306

${ }^{7}$ Id, article 3244-3296
} 
otherwise.

The following parameters should be used to determine whether certain government entity is administrative authority/agency or otherwise. ${ }^{1}$

The nomenclature used to describe the entity such as ministry, authority, agency, bureau, office, commission, board or similar terms, that it has legislative and/or adjudicative power granted by the legislatures and That the head of agency/authority is appointed by the executive or the house of peoples' representatives.

Therefore, the foregoing analysis reveals that administrative contracts are contracts that are expressly qualified as administrative contracts by the law as in the case of concession of public service, public supply contracts and contract of public works, or where the contract is concluded between parties in which one of the parties is administrative authority to carry out the activities of public services.

The query one may raise in connection to administrative authority or administrative agency is that does it also include public enterprises? To answer this, we may get hint from the federal government determining the procedures of public procurement and establishing its supervisory agency proclamation. ${ }^{2}$ Procuring entity is public body which is partly or wholly financed by federal government budget, higher education institutions and public institutions of the like nature. ${ }^{3}$

The inference from this is that what makes an entity administrative authority is the source from which it derives income and the purpose of the organ. Accordingly, if an entity derives wholly or partly its income from the government, there is a possibility to consider it as administrative authority. This also takes to the argument that the mere fact that certain entity is a government entity doesn't make it administrative authority.

In the case between Tewodros Abera construction works Vs. Addis Ababa University in which the parties agreed in their contract to resolve the dispute arising from or in relation to the contract through the help of the consulting engineer who should give decision within 60 days and if he fails to do so to resolve through arbitration, the federal first instance court ruled that the mere fact that one of the party to contract is a government entity does not mean that the contract is administrative contract ${ }^{4}$ (translation is mine). The court ruled that the fact that the respondent is government education institution does not make the contract the respondent entered into with appellant administrative contract. ${ }^{5}$ The implication is that who is administrative authority or agency in defining administrative contract is also very controversial concept and needs address of the law (definition of law).

\section{Arbitrability of disputes emanating from administrative contracts under the Ethiopian laws: Analysis under the Ethiopian Civil code, Civil Procedure Code and Pertinent Legislations}

As far as the arbitrability of the disputes emanating from administrative contracts is concerned, scholarly writings have different opinion on the basis of the pertinent provisions of the Civil Procedure Code and Civil Code of Ethiopia.

The Civil Procedure Code envisage that no arbitration may take place in relation to administrative contracts as defined under article 3132 of the Civil Code or in any other case where it is prohibited by the law. ${ }^{6}$ Bezawork argued that there is inexistence of anything implying such restriction in the Civil Code and expresses his opinion that legislator in the Civil Code never envisaged such restriction of arbitrability which he says would have been included in the Civil Code as it is something affecting the parties freedom. ${ }^{7}$

He strengthens his position citing article 3345 of Civil Code and article of 315(4) of Civil Procedure Code which respectively provided that it is the procedure for arbitration that should be determined by Civil Procedure Code and, that the provisions of the Civil Procedure Code chapter on arbitration shall not affect the Civil Code provisions on arbitration. ${ }^{8}$

This scholarly Writing is arguing that the Civil Code article 3345 clearly enshrined that, as far as arbitration is concerned, reference to Civil Procedure Code is to determine the procedure for arbitration and the Civil Procedure Code by itself speak out under article 315(4) that the provisions of Civil Procedure Code chapter on arbitration i.e. articles 315-319 shall not affect the provisions of Civil Code on arbitration there by implying that it is not the jurisdiction of procedural law but substantive law, Civil Code, that would have determine matters amenable to arbitration and matters not amenable to arbitration, and article 315(2) of Civil Procedure Code is restricting what matters are not amenable to arbitration though there is no such restriction or even an implication

\footnotetext{
${ }^{1}$ Aberham Yohannes and Desta G/Michael, Administrative Law Material for Academic Study, 2009, p.74

${ }^{2}$ Federal government determining the procedures of public procurement and establishing its supervisory agency proclamation, proc. No.430, 2005 , Federal Negarit Gazette, $11^{\text {th }}$ year, No.15, 2005

${ }^{3} \mathrm{Id}$, article $2(\mathrm{f})$

${ }^{4}$ Tewodros Abera Construction Works Vs Addis Ababa University (Federal First Instance Court File no. 210554) (unpublished)

${ }^{5}$ Ibid

${ }^{6}$ The Ethiopian Civil Procedure Code, article 315(2)

${ }^{7}$ Bezawork Shimellash, The formation, content and effect of arbitral submission under Ethiopian law, Journal of Ethiopian Law, vol.17, 1994, p.83

${ }^{8}$ Ibid.
} 
to that effect under the Civil Code and there by defeat article 315(4).

Zekarias Keneaa argued that it is surprising to find a provision that reads "no arbitration may take place in relation to administrative contracts as defined in article 3132 of Civil Code or in other cases where prohibited by the law in the Civil Procedure Code but nothing to that effect or similar to that is stated in any one of articles 33253346 of the Civil Code." He also argued that the issue of interpretation of the two legal texts i.e. article 315(2) of Civil Procedure Code on one hand and articles 3325-3346 might as well arise and this become even more glaring if one considers article 315(4) of the Civil Procedure Code which states that nothing in this chapter shall affect the provisions of articles $3325-3346$ of the civil code. ${ }^{2}$

Accordingly, he argued that if nothing in Chapter 4 of the Civil Procedure Code affects the provisions of articles 3325-3346 of the Civil Code and nothing as to whether or not matters arising from administrative contracts are in arbitrable is mentioned in articles 3325-3346 of the Civil Code, could article 315(2) of Civil Procedure Code be given effect ${ }^{3}$ Or if the overriding texts of articles 3325-3346 are silent as to whether or not disputes emanating from administrative contracts are arbitrable; cannot that be taken as an implication that even disputes arising from administrative contracts are arbitrable in so far as nothing express is stated in articles 3325-3346 that they are nonarbitrable ${ }^{4}$ implying that the interpretation or the construction of the two legal texts tends towards to showing that disputes arising from administrative contracts is amenable to arbitration because if nothing in Chapter 4 of Civil Procedure Code affects the provisions of articles 3325-3346 of the Civil Code as per article 315(4) of the Civil Procedure Code and nothing is stated as to whether or not disputes arising from administrative contracts are in arbitrable in articles 3325-3346 of the Civil Code or it is silent, by interpretation it implies that disputes emanating from administrative contracts are arbitrable.

Thus, this scholarly writing is implying that what matters in determining whether disputes emanating from administrative contracts are arbitrable or otherwise is the interpretation or construction of article 315 of Civil Procedure Code and articles 3325-3346 of the Civil Code.

A survey of some pertinent Ethiopian legislations/proclamations reveal that there are government administrative organs that have legal mandate to resolve disputes that may arise in their legal relationship with other party through arbitration. To begin with, Ethiopian civil aviation proclamation clearly reads that:

Ethiopian civil aviation authority shall have the power and duties to own property, enter into contract, sue and be sued in its own name, and may submit dispute to the arbitration. ${ }^{5}$ This provision unequivocally indicates that the dispute that arise from contract Ethiopian civil aviation authority entered into with other party can be submitted to and settle through arbitration.

In similar vein, a proclamation to establish agency for government houses enshrined that the agency shall have the power and the duty to own property, enter into contract, sue and be sued in its own name including settlement of disputes through arbitration. ${ }^{6}$

A proclamation that defines the powers and duties of the executive organs of the federal democratic republic of Ethiopia also empowers the ministry of justice to institute or cause to be instituted or intervene in proceeding before judicial body or arbitration tribunal where the rights and the interest of the public and the federal government so requires ${ }^{7}$ which implies that the possibility of settlement of disputes in connection to that through arbitration.

Ethiopian water resource proclamation also envisaged that the supervising body (ministry of water resource or organ delegated by ministry per article 2(8) of the proclamation) .... "In the event that the agreement can't be reached through negotiations pursuant to sub-article (3) of this article, the case shall be settled by arbitration."

Thus, a survey of these laws or proclamations which allow these government administrative organs to resolve disputes that may arise from the legal relationship they enter into with other party through arbitration show that there is possibility of settling disputes that may arise from administrative contracts that these government administrative organs concluded with other party through arbitration.

These may be taken as clear instance where disputes emanating from contract entered into between government administrative organs and other party can be capable of settlement through arbitration i.e. arbitrable.

Therefore, the possible critical thinking may be raised at this juncture is that how these laws are going to be seen in light of article 315(2) of the Civil Procedure Code even if we take it as mandatory provision. Can we take them as exceptions assuming that article 315(2) of the Civil Procedure Code prohibits disputes arising from

\footnotetext{
${ }^{1}$ Zekarias Keneaa, Supra Note 5, p.119

${ }^{2}$ Ibid.

${ }^{3}$ Ibid

${ }^{4}$ Ibid.

${ }^{5}$ Civil aviation proclamation, proc. No. 616, 2008, article 10(18), Federal Negarit Gazette, $5^{\text {th }}$ year, no. 23,2009

${ }^{6}$ Agency for the government houses establishment proclamation, proc. No. 555, 2007, article 6(11), Federal Negarit Gazette, $14^{\text {th }}$ year, No. 2 , 2007

${ }^{7}$ Definition of powers and duties of the executive organs of the federal democratic republic of Ethiopia proclamation, proc. No. 4, 1995, article 23(8), Federal Negarit Gazette, $1^{\text {st }}$ year, no. 4, 1995

${ }^{8}$ Ethiopian Water resource Management proclamation, proc. No. 197, 2000, article 9(4), Federal Negarit Gazette, $6^{\text {th }}$ year, No.25, 2000
} 
administrative contracts to be settled through arbitration (can we take it as list of exceptions) or can we say these proclamations amended the provision of article 315(2) of Civil Procedure Code? I am in the position that these laws amended this provision of the Civil Procedure Code with regard to disputes emanating from the matters the proclamations are addressing provided that it is prohibitive clause.

My argument is that the provision of article 315(2) of the Civil Procedure Code doesn't prohibit disputes emanating from administrative contracts from being arbitrable if we strictly interpret article 315(4) of the same code where there is no prohibition of settling dispute from administrative contracts through arbitration or similar to that is provided under the provisions of the civil code dealing with arbitration, or if we take it as prohibitive clause these proclamations amended this provision of the Civil Procedure Code. This, on the other dimension, conveys the message that the government can prohibits or permits, as it thinks fit through laws or proclamations, disputes arising from administrative contracts concluded between government administrative organs with other parties to be settled through arbitration. This may have its own effect on the justice system.

\section{What the practice looks like as to the arbitrability of disputes emanating from administrative contracts in Ethiopia?}

It is indisputable that the issues of arbitrability of disputes emanating from administrative contracts in Ethiopia become very controversial as we can observe from various scholarly articles, judicial interpretation of arbitrability on the point at issue as well as the opinion of individuals or academicians. Having seen the arbitrability of disputes emanating from administrative contracts under Ethiopian laws, now let us see what the practice looks like as to the same issue.

\subsection{The practice before the courts}

It is vivid fact that the issue of arbitrability of disputes emanating from administrative contracts is traced back to the early of 1960s after the enactment of the civil code and civil procedure code. The point here is that how the courts deal with the matter. This practice before Ethiopian courts as to arbitrability of disputes emanating from administrative contracts is reflected in the decided cases on the subject matter under study as we can observe from the cases dealt with hereunder.

In the case between Highway Authority vs. Solel Boneh Ltd the imperial supreme court of Ethiopia affirmed the decision of the then High court ordering the government agency to comply with a clause of its contract with Solel Boneh Ltd that provided for the submission of all disputes under the contract to arbitration. ${ }^{1}$

"In Ethio-Marketing Ltd vs. Ministry of information the decision of the court reads that a contract concluded between parties pursuant to the provisions of the civil code is a law between the parties. The appellant and Respondent having, on the basis of the civil code, agreed to resolve the dispute between them by arbitration, the civil procedure code shouldn't prevent the enforcement of the contractual agreement."2

According to Tekle Hagos, the decision of the court was based on the argument that procedural laws should neither limit nor extends substantive rights though it is too difficult to maintain the argument. ${ }^{3}$

In Water supply and Sewage authority Vs. Kundan singh Construction Limited, the then High court rejected the argument of the Indian party that article 315(2) of civil procedure code should not be given effect since the overriding substantive law is silent as to the in arbitrability of the issues arising from the administrative contracts and ruled that this provision of civil procedure code exclude disputes arising from administrative contracts from settlement by arbitration. ${ }^{4}$ In justifying its position, the court argued that "the question relating to which court or tribunal has jurisdiction is a matter of procedure and that procedural matters are provided for in the civil procedure code, not in the civil code". The other argument raised by the court to justify its ruling is that matters relating to administrative contracts are in arbitrable under the French law (French code of civil procedure prohibits matters related to administrative contracts from arbitration) from where our civil code is taken. ${ }^{6}$ However, the court's decision has been seen by some commentators as unconvincing endeavor to get around the strong point under article $315(4){ }^{7}$

In the Zem zem Plc vs. Ilu Abbabor Zonal Department of education ${ }^{8}$ in which they agreed to settle dispute that arises out of contract concluded between them for construction of elementary school which falls under contracts of public works (article 3344 civil code et seq) amicably through informal negotiation, if no amicable

\footnotetext{
${ }^{1}$ Imperial Highway authority Vs. Solel Boneh Ltd (Supreme Imperial court civil Appeal No. 670/57) Mizan Law Review, Vol.4, No.2, 2010

${ }^{2}$ Ethio Marketing Ltd vs. Ministry of Information (Ethiopian supreme court decision, March 29, 1975), Mizan Law Review vol.3, No.1, p.19

${ }^{3}$ Tekle Hagos, Arbitrability of Government Construction Disputes” Mizan Law Review, vol.3 No.1, p.19

${ }^{4}$ Water supply and Sewage authority Vs. Kundan singh Construction Limited (Addis Ababa High court, Civil File No.688/1979), Mizan Law Review, vol.4, No.2, 2010, p.314

${ }^{5}$ Ibid

${ }^{6}$ Ibid

${ }^{7}$ Zakarias Keneaa, Supra Note 5, p.120

${ }^{8}$ Zem zem Plc vs. Illubabor Zone Education Department (federal supreme Court Cassation File No.16896, 1998), Mizan Law Review, vol.3 No.1, p. 21
} 
solution by negotiation either party may require that dispute be referred to adjudication or arbitration, the Federal supreme court Cassation division ruled in its holding that the term of the contact is clear and doesn't need interpretation, and the contractual agreement entered into between the parties is a law and binding by virtue of article 1731 of the civil code there by reversed the decision of Oromiya Supreme court and ordered the Illubabor Zonal Bureau of Education to go to about settling its dispute with appellant through arbitration. ${ }^{1}$ The federal Supreme Court cassation bench by this decision "hammered the final nail on article 315(2)'s coffin" thereby make any arbitral clause or submission in administrative contracts enforceable. ${ }^{2}$ This means the decision of federal Supreme Court cassation bench is binding over decision of courts. ${ }^{3}$

The point here is that how we will treat article 315(2) of the civil procedure code if the decision of the federal Supreme Court cassation division is binding over all courts, be it federal or regional (state) courts. The possible convincing argument is that the provision of article 315(2) of civil procedure code is repealed by this federal Supreme Court cassation bench decision.

Tekle argued that the lesson we may draw the from this decision of the federal Supreme Court cassation division decision is that the court has stripped article 315(2) of the civil procedure code by hammering the last nail in its coffin and thereby permits any arbitral clause or submission in administrative contracts is enforceable, and the federal supreme court cassation bench erred in holding the decision that is unequivocally against clear public policy consideration of non-arbitrability of the administrative contracts disputes enshrined under article $315(2)$ of the civil procedure code. ${ }^{4}$

In the case between Tewodros Abera construction works Vs. Addis Ababa University in which the parties agreed in their contract to resolve the dispute arising from or in relation to the contract through the help of the consulting engineer who should give decision within 60 days and if he fails to do so to resolve the dispute through arbitration, the federal first instance court ruled that the mere fact that one of the party to contract is a government entity does not mean that the contract is administrative contract and the court ruled that the dispute arising from their agreement should be decided through arbitration according to their agreement. ${ }^{5}$

The point we can infer from the aforementioned discussion of the practice before courts as to the arbitrability of disputes emanating from administrative contracts in Ethiopia is that some courts treat the disputes arising from administrative contracts as arbitrable whereas other courts treat the same as in arbitrable. This creates the controversy over the matter to continue.

\section{Conclusion}

Dispute which refers to a conflict or controversy or conflict of claims or rights may possibly arise from or in relation to contract concluded between the contracting parties or certain defined legal relationship between the parties. And it may be resolved outside of the courts through the alternative dispute resolution mechanisms based the agreement of the contracting parties. Arbitration is one of the mechanisms to achieve this end. But due to public policy related considerations of a country some matters are amenable to arbitration (arbitrable) whereas other matters are not amenable to arbitration (in arbitrable).

Whether disputes arising from administrative contracts are arbitrable or otherwise is a point of controversy in Ethiopia starting from the 1960s. This divergence is primarily based on article $315(2) \&(4)$ of civil procedure code on one hand and articles 3325-3346 of the civil code on the other. This leads one to critically wonder whether article 315(2) of the civil procedure code is prohibitive clause, if so, what is the purpose of article $315(4)$ of the same code, or is not prohibitive clause or should not be prohibitive clause where there is nothing that prohibits or to that effect is envisaged or even inferable in articles 3325-3346 of the civil code. The other critical point one may raise in connection to this is how to treat article 315(2) of the civil procedure code in light of the proclamations which gives legal mandate to some administrative organs of the government to settle their dispute through arbitration.

Above all, the decisions of the Federal Supreme Court cassation bench in the case between Zem zem Plc vs. Illubabor Educational Bureau File no.16896, 1998 "hammered the last nail in article 315(2)'s coffin" there by ensures disputes emanating from administrative contracts arbitrable and enforceable as the decision of Federal Supreme Court Cassation Division is binding under Ethiopian Legal system.

Therefore, these all aids to find as well as argue that disputes emanating from administrative contracts are arbitrable in Ethiopia.

\section{Recommendations}

Since the arbitrability of disputes arising from administrative contracts are very controversial in Ethiopia, the

\footnotetext{
${ }^{1}$ Tekle Hagos, Supra Note 30, p. 22

${ }^{2}$ Id, p. 27

${ }^{3}$ Federal Courts Establishment Proclamation, Proc. No. 25, 1996, article 10, Federal Negarit Gazette, $2^{\text {nd }}$ year, No. 13 , 1996

${ }^{4}$ Tekle Hagos, Supra Note 24, p.27

${ }^{5}$ Tewodros Abera construction works vs. Addis Ababa University, cited above at note 15
} 
government or the concerned body:

* Need to undertake further research to come up with the possible solutions.

* Should address the alleged controversy of the pertinent provisions of the Ethiopian Civil Code and Civil Procedure Code

- Should have administrative procedure law which helps to address the controversy in relation to administrative agencies or authorities in identifying administrative contracts.

* Need to address the issue pertaining to arbitrability of administrative contracts under the Civil Procedure Code vis-à-vis Proclamations which clearly authorize or mandate some government administrative organs to resolve their dispute through arbitration.

\section{REFERENCES}

\section{Journal Articles}

Bezawork Shimellash, The formation, content and effect of arbitral submission under Ethiopian law, Journal of Ethiopian Law, vol.17, 1994

Tekle Hagos, arbitrability of government construction Disputes, Mizan Law Review, vol.3 No.1

Zakarias Kaneaa, Arbitrability in Ethiopia: Posing problem, Journal of Ethiopian Law, vol.17, 1994

\section{Books}

Aberham Yohannes and Desta G/Michael, Administrative Law Material for Academic Study, 2009

Wondwossen Wakene, Law of Administrative Contracts Materia for Academic Study, 2009

Cases

Ethio- Marketing Ltd vs. Ministry of Information (Ethiopian Supreme Court Decision, March 29, 1975), Mizan Law Review, vol.3, No.1

Imperial Highway authority Vs. Solel Boneh Ltd (Supreme Imperial Court Civil Appeal No. 670/57) Mizan Law Review, Vol.4, No.2

Tewdros Abera Construction Works Vs Addis Ababa University (Federal First Instance Court File no. 210554) (unpublished)

Water supply and Sewage Authority Vs. Kundan Singh Construction Limited (Addis Ababa High court, Civil File No.688/1979), Mizan Law Review, vol.4, No.2, 2010

Zem zem Plc vs. Illubabor Zone Education Department (Federal Supreme Court Cassation File No.16896, 1998), Mizan Law Review, vol.3 No.1

\section{Law Codes}

The Civil Code of Empire of Ethiopia, Proclamation No. 165 of 1960

The Civil Procedure Code of the Empire of Ethiopia, Negarit Gazette Extra ordinary issue No.3 of 1965

Legislations

Agency for the Government Houses Establishment Proclamation, proc. No. 555, 2007, Federal Negarit Gazette, $14^{\text {th }}$ year, No. 2, 2007

Civil Aviation Proclamation, Proc. No. 616, 2008, Federal Negarit Gazette, $5^{\text {th }}$ year, No. 23, 2009

Definition of Powers and Duties of the Executive Organs of the Federal Democratic Republic of Ethiopia Proclamation, proc. No. 4, 1995, Federal Negarit Gazette, $1^{\text {st }}$ year, No. 4, 1995

Ethiopian Water Resource Management Proclamation, Proc. No. 197, 2000, Federal Negarit Gazette, $6^{\text {th }}$ year, No. 25,2000

Federal Courts Establishment Proclamation, Proc. No. 25, 1996, Federal Negarit Gazette, $2^{\text {nd }}$ year, No. 13, 1996

Federal Government Determining the Procedures of Public Procurement and Establishing its Supervisory Agency Proclamation, proc. No.430, 2005, Federal Negarit Gazette, $11^{\text {th }}$ year, No. 15,2005

\section{Websites}

$<\mathrm{a}$ href="http://legal-dictionary.thefreedictionary.com/dispute" $>$ dispute $</ \mathrm{a}>$, accessed on 16, February, 2019.

https://en.wikipedia.org/wiki/Arbitration, accessed on 16, February, 2019 